\title{
Prikaz oplemenjivačkih programa na vinovoj lozi (Vitis vinifera L.) u Europi
}

\section{Sažetak}

Moderna vinogradarska i vinarska proizvodnja bazira se na dominantnom korištenju malog broja dobro poznatih sorata koje pripadaju plemenitoj vrsti vinove loze (Vitis vinifera L.), a koje su izuzetno osjetljive na glavne bolesti prisutne u uzgoju kao što su plamenjača (Plasmopara viticola Berk \& Curt.) i pepelnica (Erysiphe necator Schwein.). Promjene sortimenta u uzgoju veoma su spore zbog konzervativnog $i$ tradicionalnog stava proizvođača kao i potrošača grožđa i vina. Vinogradarska je proizvodnja jedan od najvećih potrošača pesticida, posebno fungicida i insekticida u odnosu na sve druge vrste proizvodnih sustava u poljoprivredi i kao takva ima izuzetno negativan utjecaj na okoliš, ali i zdravlje ljudi koji rade u vinogradarskom sektoru. Danas su u svijetu pokrenuti brojni oplemenjivački programi s ciljem stvaranja novih sorti otpornih na bolesti koje će svojom kvalitetom i drugim karakteristikama biti usporedive s tradicionalnim sortama pojedinih područja. U ovom radu iznesene su najvažnije oplemenjivačke metode i programi koji se danas provode na vinovoj lozi u Europi.

Ključne riječi: Vitis vinifera, otporne sorte, hibridi, oplemenjivanje

\section{Uvod}

Najveći izazovi uspješne vinogradarske proizvodnje su biotički čimbenici: fi

a (Daktulosphaira vitifoliae Fitch) i gljivične bolesti poput plamenjače ( $P$. viticola), pepelnice (E.necator) i sive plijesni (Botrytis cinerea, Persoon) uz abiotičke čimbenike sve prisutnijih klimatskih promjena.

Vinova loza globalno je jedna od najznačajnijih višegodišnjih biljnih vrsta koja je 2018. godine zauzimala 7,4 milijuna hektara poljoprivrednih površina. lako grožđe ima mnogo namjena i dalje se najveća količina, 57 \% prerađuje u vina. Posljednjih dvadesetak godina se u svijetu godišnje proizvodi prosječno $270 \mathrm{mhl}$ vina, a prema zadnjim dostupnim podatcima, 2018. godine je ukupno proizvedeno $292 \mathrm{mhl}$ vina, čija se ekonomska vrijednost mjeri u desecima milijardi eura (OIV, 2019.).

Na većini vinogradarskih položaja u svijetu, da bi se vinova loza uopće mogla uzgajati i davati redoviti rod - potrebne su mnogobrojne intervencije u vidu agro- i ampelotehničkih zahvata, uz značajan utrošak fitosanitarnih sredstava, što utječe na vrijednost i troškove proizvodnje istovremeno čineći veliki pritisak na dugoročno i nepovratno onečišćenje okoliša.

U konvencionalnoj vinogradarskoj proizvodnji, usprkos prisustvu raznih dugogodišnjih selekcijskih i oplemenjivačkih programa koji su dosad rezultirali s gotovo osam tisuća novoregistriranih interspecijes hibridnih sorata u Vitis internacionalnom katalogu (www.vivc.de), još uvijek 50 \% ukupnih površina zauzimaju svega 33 tradicionalne sorte vinove loze (OIV, 2017.). Takve sorte još nazivamo i,,kozmopolitima“ ili internacionalnim sortama, koje iako daju izrazito kvalitetna vina, nastale su prije više stotina godina spontanom hibridizacijom i za većinu je karakteristična iznimna osjetljivost na najvažnije bolesti. Prema Anderson i Aryal (2020.), 2016. godine je najraširenija crna vinska sorta bila Cabernet Sauvignon, sa gotovo 7 \% udjela u ukupnoj globalnoj površini pod vinogradima, a bijela sorta Airén sa 4,5\% udjela. Ukoliko bi se zbrojili udjeli pet najraširenijih crnih i bijelih sorata, dobili bismo okvirno 41,5 \% ukupne svjetske proizvodnje vina. 
Uzevši u obzir kako već stoljećima mali broj sorata, odnosno populacija istog genotipa, raste diljem planete u raznim agroekološkim uvjetima na ogromnim površinama, na kojima se zbog velikog pritiska bolesti mora učestalo prskati pesticidima, nije ni čudno da se sve češće susrećemo s pojavom rezistentnih sojeva bolesti i štetnika na danas poznata sredstva za zaštitu bilja. Uz sve veći rast ekološke osviještenosti, posljednjih 15 godina bilježimo rast površina pod ekološkim vinogradarstvom, koje je u 2018. sa 422000 ha doseglo razinu od 6,1 \% ukupne vinogradarske proizvodnje (FIBL i IFOAM, 2020.).

Ekološka vinogradarska proizvodnja prepoznaje i potiče uzgoj novih,,sorata s otpornosti na gljivične bolesti“ tzv. FRG / PIWI sorte, shvaćajući kako je genetska otpornost prema najvažnijim bolestima i štetnicima jedino dugotrajno, sigurno, održivo i ekonomski isplativo rješenje, a kako je prisutan sve veći interes proizvođača i potrošača za ekološki proizvedenim vinima, tako bi i tržište moralo biti spremnije na prihvaćanje novih sorata, ukoliko se njihova vina pokažu kvalitetnijima ili barem u razini sa konvencionalnim vinima tradicionalnih sorata (Pedneault i Provost, 2016).

Vinarski je sektor i prateća legislativa u proizvodnji, neovisno o sve brojnijim otkrićima i uspješnijim rezultatima oplemenjivačkih aktivnosti napretkom molekularnih i biotehnoloških metoda, posebice u „zemljama starog svijeta“, još uvijek veoma tradicionalan i samo tržište oblikuju navike potrošača, koji u najvećem broju prilikom kupovine vina obraćaju pozornost na dobro znanu i provjerenu sortu, zbog čega je veoma teško introducirati novi sortiment (Eibach i Töpfer, 2015). Osim toga, zbog loših oplemenjivačkih rezultata u prošlosti, još je uvijek prisutno preveliko nepovjerenje prema kvaliteti vina od nepoznatih sorata i takozvanim,,hibridima“. Zbog svega navedenog, iako otporne sorte iskazuju veliki potencijal i rješenje najvećih problema vinogradarstva, teško se i uz dugotrajne napore, probijaju na tržište i dobivaju na broju pobornika.

\section{Metode koje se koriste u oplemenjivanju vinove loze}

Prema Maletić i sur. (2008.) „oplemenjivanje vinove loze podrazumijeva skup metoda i postupaka kojima se stvara osnova za proizvodnju sadnog materijala poboljšanih nasljednih agronomskih svojstava, tj. onih koja se prenose i zadržavaju vegetativnim razmnožavanjem."

Ciljane oplemenjivačke aktivnosti na vinovoj lozi započete su još početkom devetnaestog stoljeća u Sjevernoj Americi, odnosno krajem istog stoljeća u Europi, nakon introdukcije filoksere i gljivičnih bolesti u europske vinograde iz Amerike (Eibach i Töpfer, 2015.). Spomenute su se aktivnosti odvijale prije otkrivenja Mendelovih zakona genetike, a i znatno prije nego što je otkrivena struktura molekule DNK. Prvi oplemenjivački pokušaji stvaranja direktno rodnih hibrida križanjem američkih vrsta roda Vitis sa plemenitom vinovom lozom, imali su loše rezultate u pogledu kvalitete dobivenog grožđa, no unatoč tome, njima je stvorena nova genetska varijabilnost, odnosno vrijedni genetski izvori, koji su se godinama koristili u oplemenjivačkim programima, posebice za otpornost prema gljivičnim bolestima (Bavaresco, 2019.).

Reynolds i sur. (2015.) navode brojne ciljeve oplemenjivačkih programa na vinovoj lozi. U proizvodnji podloga primarno je njihova svrha rješavanje krize izazvane fi om ili prilagodba na abiotičke stresore poput suše i visoke koncentracije fi i aktivnog vapna u tlu. Uz navedeno, svrha je oplemenjivačkih programa na vinovoj lozi poboljšanje kvalitete postojećih vinskih i stolnih sorata hibridizacijom, kao i stvaranje sorata s otpornošću na najvažnije biotičke stresore koji koče održiv uzgoj vinove loze. Navedeni su ciljevi klasičnim oplemenjivačkim metodama gotovo i nedostižni, jer su neka od najvažnijih agronomskih obilježja vinove loze poput prinosa, kakvoće grožđa, bujnost i tolerantnost prema bolestima i štetnicima, kontrolirana velikim brojem gena manjeg pojedinačnog učinka na čiju ekspresiju značajno utječe okolina (Maletić i sur., 2008.). Bez uporabe pojedinih biotehnoloških metoda poput mikrocijepljenja i ostalih in vitro metoda za 
umnožavanje sadnog materijala ili poboljšanje zdravstvenog statusa vinove loze (eliminacijom virusa), danas ne bi bilo moguće na tržištu pronaći zdravi klonski materijal (Dalla Costa i sur., 2019.). U proizvodnji stolnog grožđa danas dominiraju hibridne sorte. Oplemenjivanje vinove loze u pogledu otpornosti na bolesti, uz zadržavanje primjerene kvalitete kakvu zahtijeva vinsko tržište, mukotrpan je i dugotrajan proces s nesigurnim ishodom (Regner, 2015).

\section{Klasično oplemenjivanje-hibridizacija}

Klasična oplemenjivačka strategija je izrazito skup i dugotrajan proces. Uzgoj i održavanje biljaka dobivenih križanjem, brojne fenotipske evaluacije i terenska ispitivanja potrebna u takvom programu, radi opažanja nasljeđivanja željenih karakteristika, njihove stabilnosti i ekspresije u različitim uvjetima, zahtijevaju značajne vremenske, financijske, prostorne i ljudske resurse (Eibach i Töpfer, 2015.). Oplemenjivački programi otpornosti prema najvažnijim bolestima uključuju višekratna pseudopovratna križanja s plemenitim sortama Vitis vinifera L. subsp vinifera radi unošenja što više kvalitativnih značajki važnih za vino kao finalan proizvod i radi razvitka introgresijskih linija (Töpfer i sur, 2011.).

Važno je istaknuti kako je dobivanje rezultata oplemenjivanja na većinu agronomski važnih svojstava kod vinove loze dodatno oduženo, zbog potrebe čekanja njezinog dolaska u rod, što uzrokuje vremenski razmak od 3 do 5 godina između pojedinog koraka križanja (Eibach i Töpfer, 2015.). Dodatni prilog kompleksnosti klasičnog oplemenjivanja jest visok broj različitih kombinacija mogućih genotipova (274 milijarde) uslijed križanja dviju sorata s različitom genetskom pozadinom, uzevši u obzir i visok stupanj heterozigotnosti vinove loze (Regner, 2015.). Rezultat samo jednog križanja nije predvidljiv kao ni postizanje željene kombinacije kromosoma u potomstvu. Čitav radni vijek oplemenjivača nije dovoljan za ispitivanje rezultata tog križanja.

Općenitu shemu klasičnog oplemenjivačkog programa (slika 1.) u trajanju od 25 do 30 godina uz pomoć razvoja molekularnih markera danas je moguće skratiti za 5 do 10 godina.

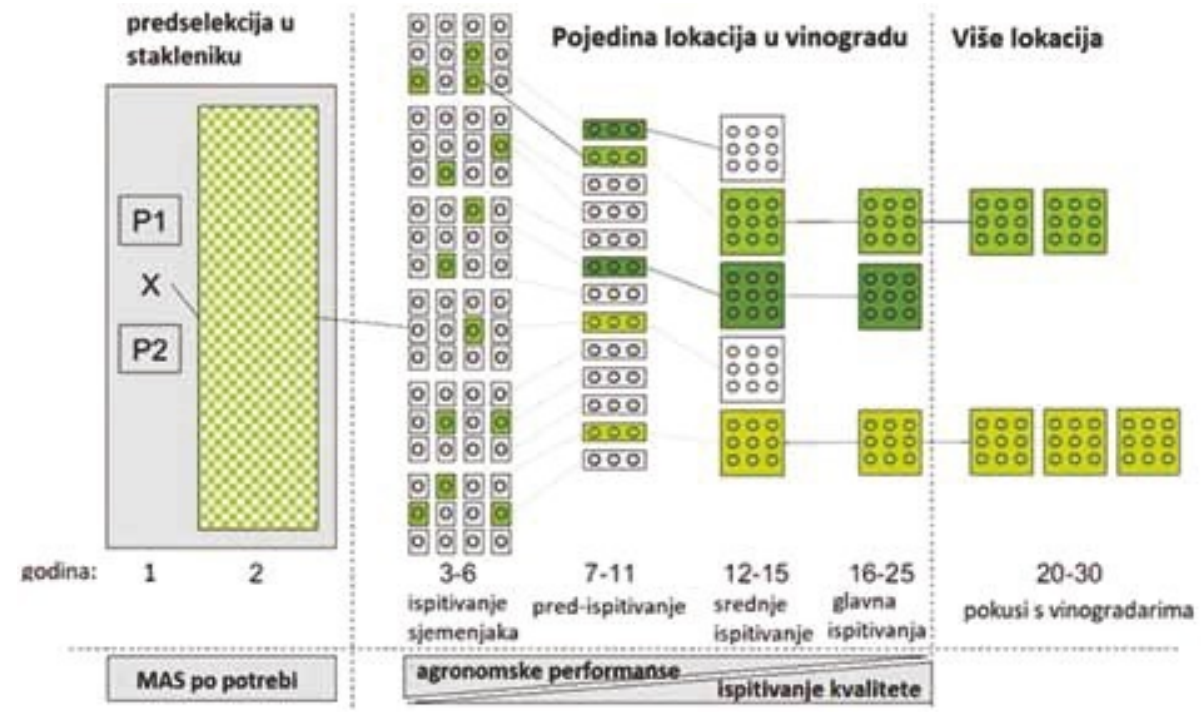

Slika 1. Prikaz klasičnog oplemenjivačkog procesa, koju aplikacija molekularnih markera može skratiti za desetak godina

Figure 1. Overview of the classical breeding process, which the application of molecular markers can shorten by ten years

Izvor/Source: Töpfer i sur./et al. 


\section{Markerima potpomognuta selekcija (MAS - Marker assisted selection)}

Značajan napredak molekularnih i biotehnoloških metoda krajem devedesetih godina omogućio je razvoj genetskih mapa vinove loze (Lodhi i sur, 1995. iz Buonassisi i sur, 2017.). Otkriveni su gen-lokusi za kvantitativna svojstva, eng. Quantitative trait loci-QTL (Fischer i sur., 2004.), a razvoj molekularnih markera (Dalbó, 1998.; Dalbó i sur, 2001. iz Eibach i sur, 2007.), omogućio je primjenu „markerima potpomognute selekcije“ i označio početak ere,molekularnog oplemenjivanja“ (Shidfar i sur., 2019.).

MAS je dovela do svojevrsne revolucije na području oplemenjivanja vinove loze. Široko je prihvaćena od strane znanstvenika i pratećih institucija zbog optimizacije i povećanja učinkovitosti oplemenjivačkog procesa, smanjenja troškova, prostornih resursa koji su bili potrebni za klasično oplemenjivanje te vremena potrebnog za dobivanje nove sorte željenih karakteristika. Razni autori navode kako je danas MAS postala uobičajena praksa diljem svijeta i jedino je sredstvo za uspješno piramidiziranje gena za određenu otpornost na bolesti (Peterlunger i sur., 2003., Eibach i sur., 2007., Sánchez-Mora i sur., 2017., Saifert i sur., 2018., Schneider i sur., 2019., Shidfar i sur., 2019.).

Uporaba molekularnih markera omogućava ciljani odabir roditelja s potencijalom za kombiniranje većeg broja različitih lokusa otpornosti u potomstvu kako bi se povećao stupanj $\mathrm{i}$ dugotrajnost otpornosti što je i cilj markerima potpomognute piramidizacije (MAP) (Eibach i Töpfer, 2015.). Uporabom MAS, moguća je brza i učinkovita pred-selekcija potomstva s naslijeđenim genima od interesa čime se u ranim stadijima oplemenjivačkog programa eliminiraju nedefinirani potomci i smanjuje veličina hibridne populacije, što uzrokuje značajnu uštedu vremena i ostalih resursa (Di Gaspero i Cattonaro, 2010.). Prema Riaz i sur., (2019.) druga najvažnija prednost MAS-a je mogućnost dobivanja kombinacije oblika otpornosti iz više genetskih pozadina u jednoj biljci. Kombinacijom ove metode i optimizacijom uzgojnih uvjeta, postignut je dvogodišnji ciklus „od sjemenke do sjemenke“, koji je omogućio razvoj novih sorata s otpornošću na bolesti s kvalitetom grožđa poput $V$. vinifere u 12 godina, za razliku od klasičnih 25-30 godina. Unatoč velikom broju različitih vrsta molekularnih markera, u oplemenjivačkim programima za otpornost na vinovoj lozi najčešće se koriste „mikrosateliti“, tzv. SSR markeri koji su specifični za određen lokus i kodominantni (Meredith, 2001.; Zini i sur., 2015.; Shidfar i sur., 2019.). Novu generaciju markera predstavljaju SNP markeri (Dong i sur., 2010.; Tomic i sur., 2013.; Weising, 2005.).

Zahvaljujući brojnim otkrićima i napretku u kontekstu razvoja i primjene molekularnih markera, genetskog mapiranja i sekvenciranja potpunog genoma vinove loze, mnogo je naučeno o lokaciji gena koji kontroliraju pojedinačna svojstva u genomu, kako se nasljeđuju i kako su organizirani unutar molekule (Töpfer i sur., 2011.). Osim istraživanja genoma vinove loze, Buonassisi i sur., (2017.) ističu važnost istraživanja domaćin-patogen interakcije, odnosno primjenu različitih protokola i pristupa integriranih sa komparativnim studijama kako bi se prepoznali rani odgovori na zaraze $\mathrm{i}$ istražili kompleksni obrambeni mehanizmi biljke, što je već rezultiralo identifikacijom gen-lokusa za otpornost. Pozicije dosad otkrivenih lokusa za kvantitativna svojstava (QTL) na kromosomima za neka od najvažnijih agronomskih svojstava, kao i za otpornost prema najvažnijim bolestima prikazane su na slici (2.) 


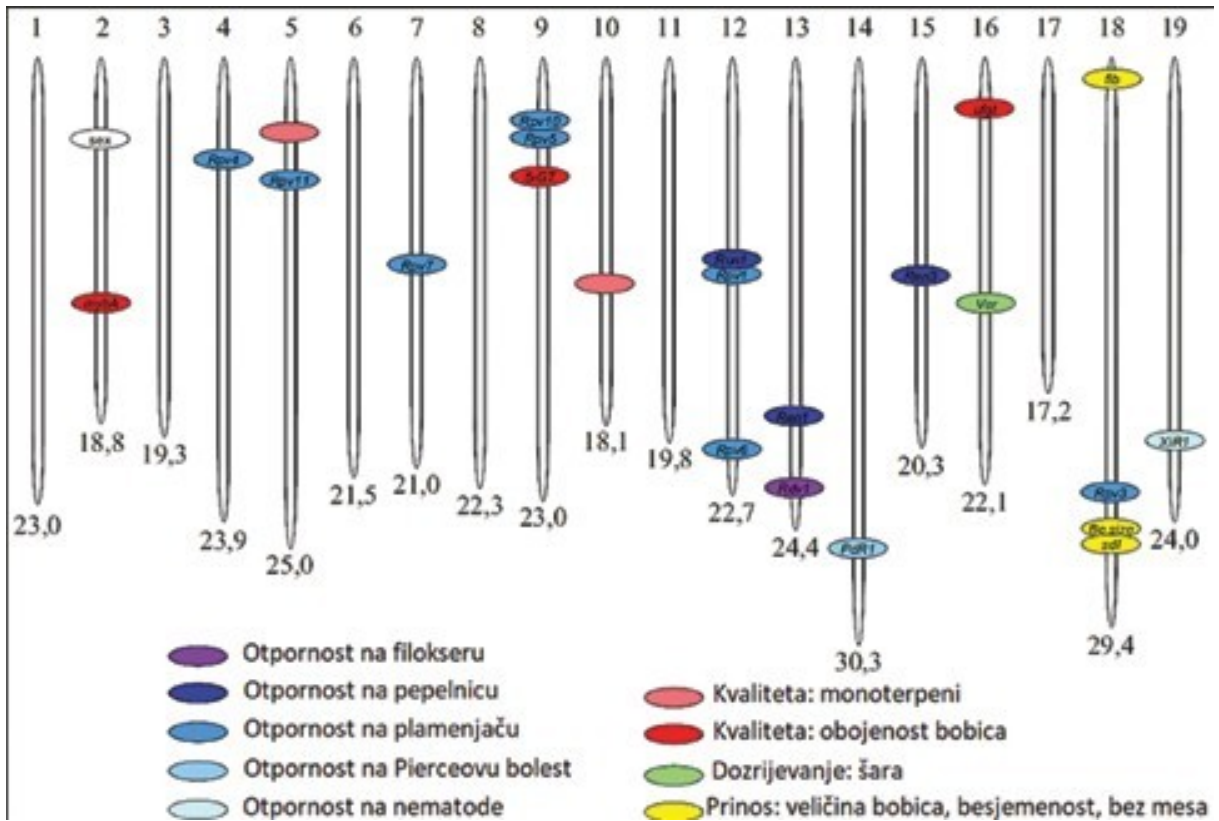

Slika 2. Pozicije lokusa za kvantitativna svojstava (QTL-ova) za najvažnija agronomska svojstva i otpornost prema patogenima

Figure 2. Loci positions for quantitative traits (QTLS) for the most important agronomic traits and resistance to pathogens

Izvor/Source: Töpfer i sur./et al.

Dostupnost ranije navedenih genomskih alata omogućila je tehničku izvedbu niza oplemenjivačkih strategija (poput MAP, MABC, MABS, AB-QTL) za precizno unošenje alela divljih vrsta, uklanjanje,,linkage drag-a“, kombiniranje više povoljnih haplotipova i selekciju poželjne genetske pozadine u novim sortama, odnosno,,precizno oplemenjivanje“ (Di Gaspero i Foria, 2015.).

lako spomenute tehnike povećavaju opseg i preciznost predviđanja ishoda uzgojnih odluka za oplemenjivače te iskazuju potencijal u postizanju veće učestalosti otpornih jedinki u budućim oplemenjivačkim programima (Shidfar i sur., 2019.), neophodno je uzeti u obzir usku genetsku varijabilnost uzgojne germplazme vinove loze zbog korištenja svega nekoliko izvrsnih darivatelja rezistencije na bolesti u dosadašnjim oplemenjivačkim programima (Di Gaspero i Foria, 2015.). Poboljšanje tradicionalnih sorata, uslijed visoke heterozigotnosti i pojave,,inbreeding“ depresije primjenom klasičnih,„cross-breeding“ tehnika, moguće je isključivo postupcima genetske modifikacije (Töpfer i sur., 2011.).

\section{Nove oplemenjivačke tehnike (NBT - New Breeding techniques)}

Prema Torregrosa i Bouquet (1993.) iz Dalla Costa i sur. (2019.), pojam biotehnologije se odnosi na bilo koji proces uzgoja, umnožavanja ili genetskog modificiranja, koji se koristi tehnikama ili uvjetima implementacije koji ne postoje spontano u prirodi, a u kontekstu vinove loze generalno mogu biti podijeljene u tri kategorije: tehnike koje se koriste za očuvanje ili umnožavanje željenih genotipova, one kojima se podržava sanitarna ili genetska selekcija elitnih sorata te tehnologije korištene za modifikaciju genetske strukture ili funkcioniranja gena poput genetske transformacije ili uređivanja genoma (Dalla Costa i sur., 2019.). U ovom će se poglavlju razmatrati treća kategorija. 
Kronološki sažetak razvoja biotehnologija kod vinove loze (tablica 1) ističe dugogodišnja istraživanja i visok potencijal razvoja naprama pristupu klasičnog oplemenjivanja. Neka od navedenih postignuća poput kulture tkiva i mikropropagacije su danas u širokoj primjeni, a posljednja otkrića iz 2016. godine svjedoče o mogućnosti modifikacije postojećih organizama bez upotrebe strane DNK.

lako su NBT prisutne duži niz godina i napretkom znanosti se konstantno poboljšavaju, kod vinove loze još uvijek nisu prihvaćene kao zamjena klasičnoj oplemenjivačkoj strategiji. Genetske modifikacije biljnog materijala, neovisno o prednostima koje nude, još uvijek nailaze na otpor javnosti primarno zabrinute za nepoznate utjecaje takvih biljaka na ljudsko zdravlje.

Tablica 1. Kronološki prikaz razvoja biotehnologije kod vinove loze

Table 1. Chronological presentation of the development of biotechnology in the grapevine

\begin{tabular}{cc}
\hline Postignuće & Izvor \\
\hline Aseptična kultura tkiva & Morel(1944.) \\
\hline Mikropropagacija & Galzy (1961.) \\
\hline Somatska embriogeneza & Mullins i Srinivasan (1976.) \\
\hline Adventivna organogeneza & Favre (1977.) \\
\hline Transgenetske loze & Mullins i sur. (1990.) \\
\hline Manipulacija agronomskim značajkama & Le Gall i sur. (1994.) \\
\hline Tehnologija protoplasta & Reustle i sur. (1994.) \\
\hline Transgenetska organogeneza & Mezzetti i sur. (2002.) \\
\hline Virusima inducirano utišavanje gena & Muruganantham i sur. (2009.) \\
\hline CRISPR/Cas9 mutageneza & Ren i sur. (2016.) \\
\hline Genetsko uređivanje bez DNK & Malnoy i sur. (2016.)
\end{tabular}

Izvor/Source: Dalla Costa i sur./et al.

\section{Genetskoinženjerstvo}

Krajem prošlog stoljeća, zaključilo se kako je najekonomičnija strategija oplemenjivanja vinove loze prijenos pojedinih svojstava u obliku pojedinačnih gena u već raspoloživu i poželjnu genetsku pozadinu željene sorte, u kojem bi slučaju bila prenesena samo željena osobina, uz minimalne poremećaje u izvornom genomu (Perl i Eshdat, 1998.). Prvi pokušaji genetskih transformacija tkiva vinove loze datiraju od samih početaka transgenetskih istraživanja, dok je prva transgenetska loza stvorena prije 30 godina. Prema Kikkert i sur. (2001.), uspješna primjena genetskog inženjerstva na vinovoj lozi zahtijeva kombinaciju učinkovitih metoda transformacije i regeneracije, identifikaciju i izolaciju korisnih gena, promotore za kontrolu ekspresije gena i uspješnu procjenu uvedenih osobina. Oplemenjivanje vinove loze genetskom transformacijom, kao i u slučaju klasičnih oplemenjivačkih programa, uglavnom je usredotočeno na otpornost na biotičke stresore poput gljivičnih bolesti i virusa, uz neke pokušaje povezane s tolerancijom na hladnoću i modificiranjem boje bobica (Saporta i sur., 2017.). Čimbenici ograničenog uspjeha su poteškoće u regeneraciji za koje je potreban razvoj adekvatnog protokola (Sabbadini i sur., 2019.), dostupnost relativno male količine karakteriziranih gena i/ili kvantitativni karakter svojstva kao i negativna percepcija potrošača za „transgenetske“ loze. Töpfer i sur., (2011.) svjedoče kako još nijedna genetski modificirana biljka vinove loze nije puštena u promet, a usprkos više različitih pokušaja unošenja poželjnih gena za unaprjeđenje otpornosti na bolesti i štetnike - konkretni se rezultati transgenetskog pristupa još uvijek čekaju. 


\section{Precizno oplemenjivanje i uređivanje genoma}

Precizno oplemenjivanje, prema Gray i sur., (2014.) pojam je koji danas zamjenjuje citagenetsko, odnosno intragenetsko poboljšanje postojećeg genoma, a odnosi se na tehnike kojima se stvara genetski modificirana biljka s jednim ili više gena koji sadrže introne i regulatorne sekvence izolirane ili iz same vrste ili iz usko povezanih vrsta sposobnih za spolnu hibridizaciju (Dalla Costa i sur., 2017.). Primjena preciznog oplemenjivanja je logično i biološki konzervativno proširenje konvencionalnog oplemenjivanja, omogućeno samo dugotrajnim znanstvenim istraživanjima, a za svoj glavni cilj ima stvaranje novih verzija elitnih sorata, koje ne samo da zadržavaju sva svoja poželjna svojstva već se njima može upravljati sa smanjenim brojem ili kompletno bez kemijskih intervencija, što se klasičnim oplemenjivačkim programima ne može postići niti u jednom praktičnom vremenskom roku (Gray i sur., 2014.). Za NBT koje u teoriji ne narušavaju fenotip postojećih sorata, smatra se kako bi vinogradarski sektor zajedno sa kupcima potencijalno mogao bolje prihvatiti u usporedbi s prethodnim GMO pristupima (Dalla Costa i sur., 2019.).

Jedno od najvećih znanstvenih dostignuća na polju biljnog genetskog inženjerstva posljednjih godina pojava je metoda „genomskog uređivanja“ putem programibilnih nukleaza. Prema Dalla Costa i sur., (2017.) pristup uređivanja genoma koristi se mehanizmima za ubacivanje ili izbacivanje neželjenih gena induciranjem prekida DNK na ciljanom mjestu, najčešće korištenjem ZFN, TALEN ili CRISPR nukleaza (enzima), koji mogu uzrokovati genetske mutacije što rezultira utišavanjem neželjenih gena. Najviše prihvaćen sustav uređivanja, CRISPR/Cas sastoji se od vodeće RNA koja sadrži ciljani slijed od obično 20 nukleotida i Cas nukleazu (često korišteni Cas9), koji cijepa dvolančanu DNK na ciljnom mjestu (Scheben i Edwards, 2017.). CRISPR/ Cas tehnika može izazvati mutacije na gotovo bilo kojem mjestu u genomu bilo kojeg organizma, a najjednostavnije se može usporediti s alatima za,,pronalaženje i zamjenu“ u programima za obradu teksta. Veillet i sur., (2020.) navode kako CRISPR/Cas metode nude veliki potencijal u povećanju proizvodnje usjeva s otpornošću na genetske bolesti. Slike 3. i 4. prikazuju princip rada CRISPR/Cas9 sistema i usporedbu klasičnog oplemenjivačkog programa s najnovijom metodom uređivanja genoma.

Glavne prednosti uređivanja genoma nad konvencionalnim i ranijim transgenim pristupima, uz kraće vrijeme za dobivanje poboljšanih sorata su niska cijena, jednostavnost upotrebe, nedostatak trajno introduciranih transgena u germplazmi usjeva i mogućnosti za istovremeno uređivanje više ciljeva, poznatije i pod nazivom,multipleksiranje“ (Cong i sur., 2013. iz Scheben i Edwards, 2017.).

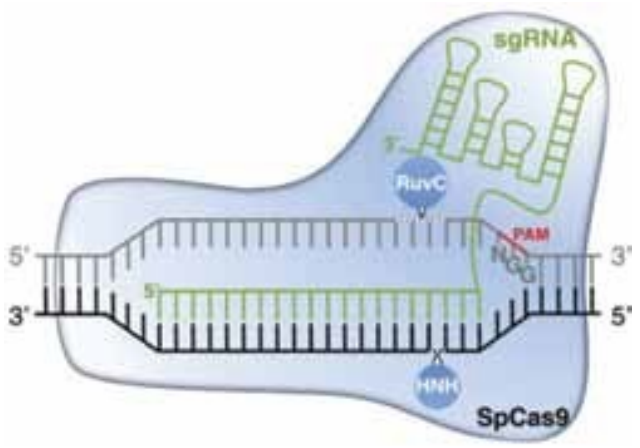

Slika 3. Princip rada CRISPR/Cas9 metode

Figure 3. Principle of operation of the CRISPR/ Cas9 method

Izvor/Source: Veillet i sur./et al.

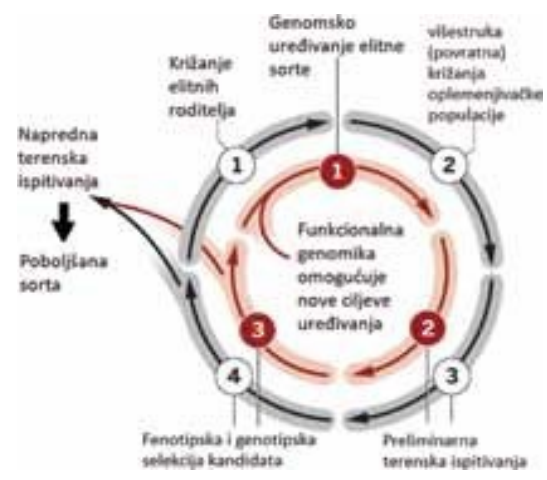

Slika 4. Usporedba klasične oplemenjivačke metode sa uređivanjem gena Figure 4.Comparison of theclassical breeding method with gene editing

Izvor/Source: Scheben, \& Edwards 
Dodatni argument za uvjeravanje potrošača i zakonodavaca u sigurnost i višestruke prednosti novih oplemenjivačkih tehnika, razvitak je transformativnih metoda koje koriste samo proteine ili protein-RNA komplekse za transformaciju, zajednički nazvanih „Genomsko uređivanje bez DNK“ (eng. DNA-Free genome editing), koje omogućuju izmjenu genoma bez upotrebe rekombinantne DNK, što bi potencijalno utjecalo na izuzimanje ovih metoda iz europske GMO legislative (Metje-Sprink i sur., 2019.). Prema Malnoy i sur., (2016.) takav je pristup posebno koristan kod vinove loze za koju su već poznata ograničenja klasičnih oplemenjivačkih aktivnosti i mogućnosti za poboljšanja trenutno poznate germplazme.

Gray i sur., (2014.) kao prepreke za praktičnu uporabu ranije navedenih metoda u dostupnim genetičkim izvorima navode potrebu za značajnim napretkom $u$ istraživanju funkcionalne karakterizacije važnih gena i promotora te održivosti izoliranih genetskih materijala, koji zaostaju za brzim napredovanjem analiza sekvenci i funkcionalnom označavanju genoma vinove loze. Velik je broj različitih radova usmjeren poboljšanju metodologije NBT, no one se, osim suočavanja s različitim tehničkim izazovima, susreću sa brojnim etičkim kritikama i sociopolitičkim ograničenjima (Dalla Costa i sur., 2017, 2019; Gray i sur., 2014; Metje-Sprink i sur., 2019; Scheben i Edwards, 2017). Svi navedeni autori raspravljaju o važnosti izuzimanja ovih metoda, posebice „uređivanja bez DNK“, iz stroge europske GMO legislative zbog činjenice da niti konačna biljka niti njezino potomstvo ne sadrže nikakav strani genetski materijal iz nesrodnih biljaka ili organizama što znači da nema nikakvih fizičkih razlika u usporedbi sa konvencionalno uzgojenim biljkama i njihovim svojstvima koji bi se teoretski mogli razviti i spontano u prirodi.

Usprkos sad već višedesetljetnim naporima znanstveno-istraživačke zajednice i ostvarenih uspješnih rezultata stvaranja genetski poboljšanih kultvara vinove loze, Sud Europske unije je i dalje ustrajan u odluci (ECLI:EU:C:2018:583) da biljni proizvodi dobiveni postupcima uređivanja genoma (koji nisu modificirani kemijskom ili fizičkom mutagenezom) potpadaju pod strogi regulatorni okvir koji se primjenjuje za GMO iz 2001/18/EC (www.curia.europa.eu) čime se realno onemogućava njihov uzgoj i puštanje u promet.

\section{Kimerizam kod vinove loze}

Prema Maletić i sur. (2008.) „kimere su mješavina tkiva različitog genotipa unutar istog organizma, a nastaju kao posljedica razmnožavanja mutiranih stanica, najčešće zbog mutacije pojedinog gena ili promijenjenog stupnja ploidnosti unutar stanice." Prema Frank i Chitwood, (2016.) kimere su formirane iz konglomeracijskih stanica koje potječu od zasebnih zigota, a ovisno o mjestu postanka i načinima daljnjih dioba dijelimo ih na periklinalne, meriklinalne i sektorijalne kimere. Slika 5. prikazuje lokaciju pojedinih vrsta kimera u meristemskom tkivu, a na Slici 6. prikazan je najpoznatiji oblik somatske varijacije kod vinove loze, odnosno mutacije L1 sloja epidermalnih stanica. Maletić i sur. (2008.) navode kako bi periklinalne kimere mogle biti od značaja za praktično vinogradarstvo jer su te mutacije ograničene na vanjski sloj meristemskog tkiva koji se zadržava vegetativnim razmnožavanjem. Ukoliko se u vanjskom sloju apikalnog meristema dogodi mutacija samo jedne stanice, zbog njezinog antiklinalnog dijeIjenja, cijeli sloj postaje genetski različit od druga dva sloja (https://irrecenvhort.ifas.ufl.edu/ plant-prop-glossary/03-genetic-selection/04-genetic-chimera.html.). Takve stanice prema Preiner, (2018.) zadržavaju svoj integritet i rastom biljke, prelaze u buduće biljne organe. 


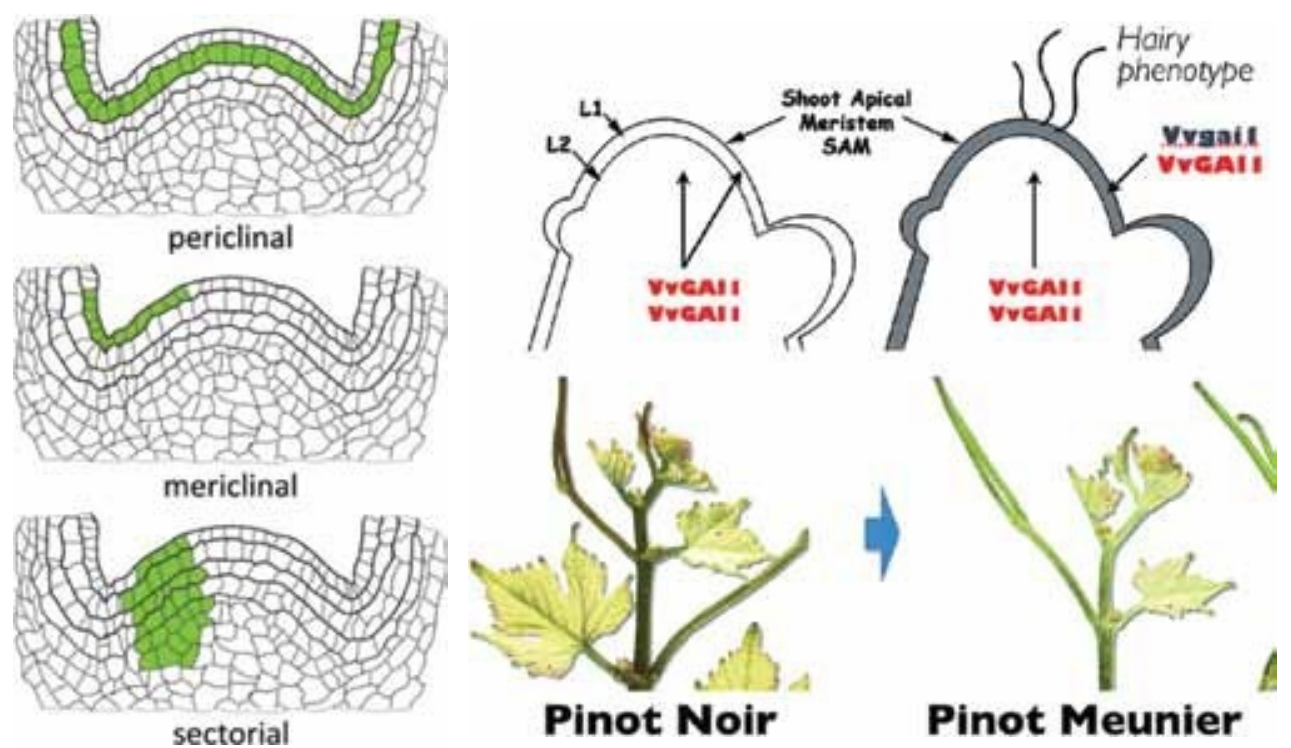

Slika 5. Lokacija kimera u meristemskom tkivu apikalnih meristema vinove loze

Figure 5. Location of chimeras in the meristematic tissue of apical meristems of the vine

Izvor/Source: https://irrecenvhort.ifas.ufl. edu/plant-prop-glossary/images/03-genetic-selection/geneticchimera/image6.png

Slika 6. Najpoznatiji oblik somatskih varijacija na vinovoj lozi

Figure 6. The most famous form of somatic variations on the vine

Izvor: https://www.researchgate.net/figure/Genetic-structures-of-pinot-noir-andpinot-Meunier-and-their-respective-apexphenotypes_fig1_333036828

Prema Frank i Chitwood (2016.) proučavanje kimera i genetskih mozaika glavne su metode za razumijevanje komunikacije unutar organizma tijekom razvoja, autonomnih i ne-autonomnih staničnih aktivnosti gena i posljedica heterogenomičnosti unutar jedinki. Franks i sur., (2002.) navode implikacije kimera za identifikaciju i utvrđivanje podrijetla sorata te genetsko poboljšanje no do nedavno u literaturi nije bilo konkretnih rezultata oplemenjivanja vinove loze sintezom kimera. Preiner i sur., (2019.) prvi su objavili rezultate uspješne sinteze intraspecifičnih kimera u in vitro uvjetima, čime su ponudili novu alternativu za oplemenjivanje vinove loze kombiniranjem već postojećih genotipova te ukazali na potencijal sinteze interspecifičnih kimera između klasičnih sorata i onih s otpornošću na gljivične bolesti, postavši pionirima na ovom još neistraženom području.

\section{Prikaz ciljeva i rezultata oplemenjivačkih programa vodećih zemalja}

Kroz sva prethodna poglavlja ovog rada, objašnjena je potreba za najrazličitijim oplemenjivačkim programima tijekom povijesti uzgoja vinove loze s fokusom na otpornost prema najvažnijim gljivičnim bolestima.

Obzirom kako je u literaturi dostupan velik broj preglednih radova (poput Sivcev i sur., 2010; Yobrégat, 2018.) i knjiga poput one Reynolds, (2015.) koji se bave povijesnim pregledom oplemenjivačkih programa na vinovoj lozi, u nastavku teksta prikazani su rezultati aktualnih programa tzv. „treće generacije“ oplemenjivačkih programa za otpornost na gljivične bolesti koji su pronašli svoje mjesto u današnjoj vinogradarskoj proizvodnji. 


\section{Francuska}

Prema Reynolds, (2015.) nakon druge polovice 20. stoljeća, kada su u Francuskoj iskrčene velike površine vinograda pod hibridima koji nisu pokazivali zadovoljavajuću kvalitetu u proizvodnji vina, oplemenjivačke aktivnosti kao i genetska istraživanja vinove loze su se nastavile s fokusom na poboljšanje sorata putem klonske selekcije plemenite vinove loze. Prema (Teissedre, 2018.) 1970-ih, oplemenjivač Alain Bouquet uspješno je ekstrahirao gene iz podroda Muscadinia rotundifolia koja je pokazivala otpornost prema mnogobrojnim bolestima i štetnicima, uključujući i gljivične bolesti te ih je višestruko povratno križao sa visokokvalitetnim vinskim i stolnim sortama $V$. vinifere kako bi se eliminiralo do 95 \% početnog genoma $M$. rotundifolie, što je rezultiralo raznolikom kolekcijom novih sorata za buduće namjene (Salmon i sur., 2018.). Prilikom evaluacije križanaca uz tolerantnost na plamenjaču i pepelnicu pomoću Rpv1 i Ren1 lokusa sa više sekundarnih gena na drugom lokusu, Bouquet je u obzir uzimao i par ostalih važnih agronomskih svojstava poput prinosa i parametara rasta, selekcionirajući sorte s visokim aromatskim potencijalom ili razinom polifenola te prilagođenim omjerom šećera i kiselina. Njegov doprinos proširenju genetske varijabilnosti vinove loze korišten je u daljnim oplemenjivačkim programima.

Schneider i sur., (2019.) svjedoče o prvim uspješnim rezultatima oplemenjivačkog programa naziva INRA ResDur, započetog 2000. godine primjenom MAS-a s ciljem kreiranja vinskih sorata sa što višom i trajnijom otpornošću na plamenjaču i pepelnicu uz odgovarajuću kvalitetu boba prikladnu za proizvodnju visokokvalitetnih vina. Riaz i sur., (2019.) navode kako je u sklopu navedenog oplemenjivačkog programa glavni cilj bio složiti (piramidizirati) gene za otpornost iz više izvora, s minimalnom funkcionalnom redundancijom, kako bi se poboljšala ujedno njihova razina otpornosti i trajnost. INRA ResDur program je rezultat međunarodne suradnje sa njemačkim Julius Kuhn institutom (JKI) i Weinbau institutom u Freiburgu te švicarskim Agroscope-om (Schneider i sur., 2019.). Slika 7. prikazuje oplemenjivačku shemu i korištene lokuse za otpornost iz različitih genetskih pozadina koja omogućava slaganje do tri lokusa rezistencije za svaku bolest. Četiri nove otporne sorte iz navedenog programa, naziva Artaban, Floreal, Vidoc i Voltis su uspješno registrirane 2018. godine u francuski nacionalni katalog, a do 2021., se očekuje registracija otprilike 8 novih sorata iz druge serije križanja. Treća bi serija, koja je prošle godine postavljena u posljednji selekcijski korak, mogla biti registrirana do 2024. godine. Ukupno je trajanje prve serije ovog programa pomoću MAS-a rezultiralo vremenskim rasponom od 15 godina od nicanja sjemenjaka do registracije u nacionalni katalog, za što je Alainu Bouquetu prema Guimier i sur., (2019.) bez MAS-a trebalo deset godina duže.

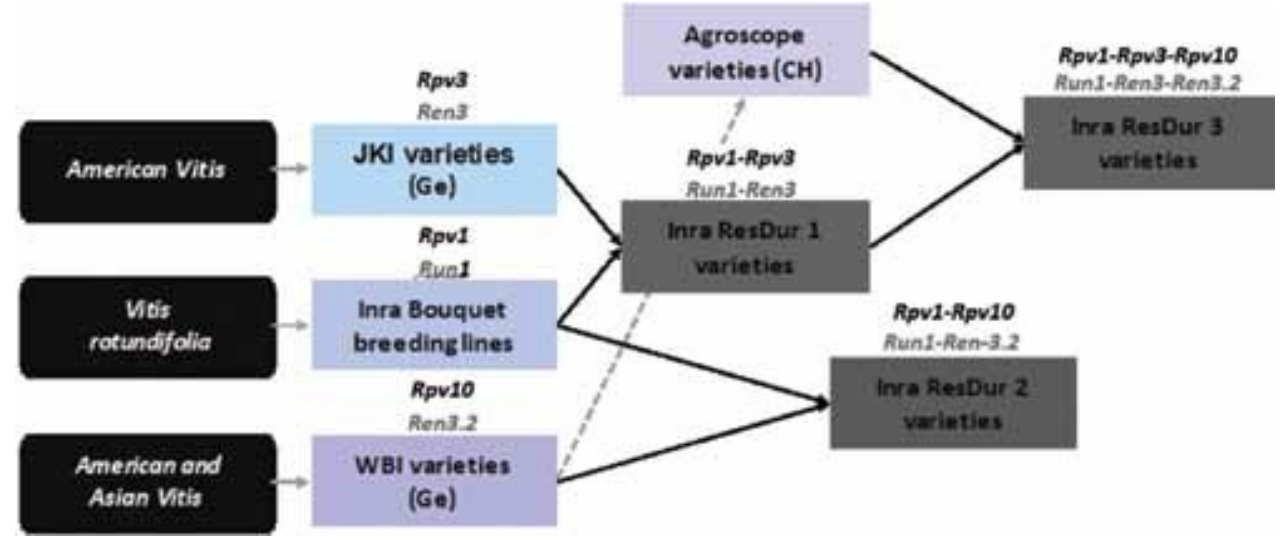

Slika 7. Shema križanja korištena u programu INRA ResDur

Figure 7. Crossing scheme used in the INRA ResDur program

Izvor/Source: Schneider i sur./et al. 
Pojedini izvori (Merdinoglu i sur., 2018; Riaz i sur., 2019.) već navode pojavu sloma rezistencije nekih lokusa poput Ren1 iz Biance, Rpv3 iz V. rotundifolie i Ren6 u otpornim sortama, što ukazuje na važnost piramidiziranja većeg broja gena $s$ različitim mehanizmima obrane od patogena za osiguravanje što veće dugotrajnosti. Teissedre, (2018.) navodi kako je prva uspješna registracija pojedinih otpornih sorata Muscaris, Souvignier, Monarch i Prior u nacionalni francuski katalog izvršena 2016. godine.

Prema Guimier i sur., (2019.), 2017. godine je pokrenut OSCAR, nacionalni opservatorij za podršku uvođenja vinskih sorata s otpornošću na gljivične bolesti u vinogradarsku proizvodnju, koji ima 3 glavna cilja: opsežno praćenje učinkovitosti otpornosti na plamenjaču, kolektivno praćenje za predviđanje razvoja populacija plamenjače i pepelnice, ali i moguće pojave novih zdravstvenih problema biljaka te poticanje razmjene iskustava na području različitih sustava uzgoja otpornih sorata u različitim vinogradarskim regijama Francuske i okolnih zemalja. Različite sorte donori poželjnih gena iz ResDur programa i ostalih oplemenjivačkih zemalja, posađene su na 17 hektara u 14 vinograda, s jednakim omjerom nasada pod ekološkim i konvencionalnim uzgojem, a tijekom prve godine promatranja primijećeno je ukupno smanjenje upotrebe fitosanitarnih sredstava za $80 \%$. U regijama s oceanskom i semi-kontinentalnom klimom bila su potrebna maksimalno 2 tretmana, u periodu pred cvatnju i šare. Tijekom praćenja pojave plemenjače i pepelnice, uslijed reduciranog broja tretiranja kroz sezonu, uočeni su simptomi crne truleži, antraknoze, akarinoze i lisne filoksere koje nisu bile ciljane genima rezistencije, no bez značajnih šteta.

Svi rezultati su javno dostupni preko službene stranice http://observatoire-cepages-resistants.fr/en/.

\section{Njemačka}

Prema posljednjem izvješću OIV-a (2019.) Njemačka je pozicionirana na 8. mjesto najvećih svjetskih proizvođača vina. Kontinuirana istraživanja uvelike su proširila varijabilnost germplazme vinove loze i dala značajne rezultate u razvoju otpornih sorata na gljivične bolesti, prihvaćenih od strane proizvođača i potrošača vina.

Oplemenjivački programi za otpornost prema pepelnici i plamenjači kontinuirano su prisutni još od 1925. godine, no posljednja dva desetljeća su nešto smanjeni i većinom bazirani na nadopunjavanju već ranije postignutih uspješnih rezultata (Ruehl i sur., 2015.). Profesor Gerhardt Alleweldt i njegov tim s Instituta Geilweilerhof zaslužni su za stvaranje prvih kvalitetnih sorata Phoenix i Regent sa zadovoljavajućom otpornošću prema plamenjači i pepelnici krajem devedesetih. Phoenix i Regent su prve sorte prihvaćene od strane vinogradara iz novih generacija otpornih sorata, a najveći uspjeh oplemenjivačkih programa za otpornost je ostvaren njihovom registracijom za proizvodnju kvalitetnih vina.

Merzling, Johanniter, Bronner, Solaris, Cabernet Carbon, Cabernet Cortis, Cabernet Carol, Muscaris, Prior, Souvignier gris, Monarch, Helios, Rondo, Orion, Sirius, Regent, Reberger, Callandro, Villaris, Felicia i Calardis su otporne sorte stvorene u Njemačkoj. (Bavaresco, 2019.) Od navedenih, sorte Merzling, Phoenix, Regent i Solaris su od 2014. godine uvrštene i u Nacionalnu listu priznatih kultivara vinove loze Republike Hrvatske (NN 53/2014) za regiju Zapadna kontinentalna Hrvatska, a ove su godine dodane sorte Cabernet Cortis i Johanniter (NN 25/2020). Njemačka i Nizozemska su jedine države koje svoje sorte s otpornošću na gljivične bolesti klasificiraju pod sorte Vitis vinifere čime se izbjegavaju određeni problemi u kontekstu korištenja ovih sorata u proizvodnji i označavanju vina. Nijemci njeguju marketing sorata s otpornošću na gljivične bolesti pod akronimom „PIWI“ (puni naziv Pilzwiderstandsfähige Rebsorten). Trenutno ovaj program broji 40 otpornih sorata, a posljednjih 9 godina objavljuju se i rezultati ocjenjivanja vina istih (https://piwi-international.de/en/ueber-piwi/piwi-grapes/). Značajan doprinos 
znanstvenoistraživačkoj zajednici, oplemenjivačima i vinskim entuzijastima, uspostava je, Vitis internacionalnog kataloga sorata" koji se od 1984. godine redovito ažurira s ciljem očuvanja i dijeljenja informacija o nazivlju sorata i otkrićima na području genetike vinove loze (https:// www.vivc.de/index.php?r=site\%2Findex). Zastupljenost otpornih i ostalih oplemenjenih sorata u vinskoj proizvodnji Njemačke je prikazana na grafu 1.

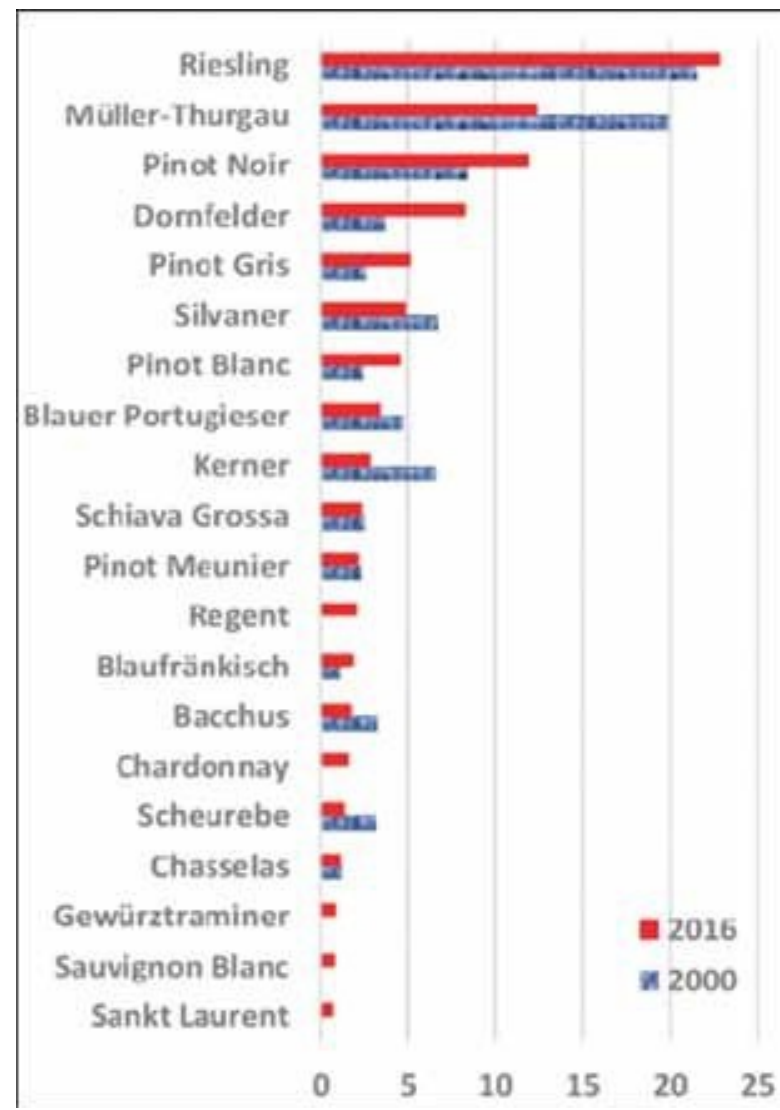

Graf 1. Prikaz trenutno najraširenijih sorata u njemačkim vinogradima, među kojima je otporna sorta Regent

Graph 1. Overview of currently the most widespread varieties in German vineyards, among which is the resistant variety Regent

Izvor/Source: http://library.oapen.org/handle/20.500.12657/33146

Njemačke sorte s otpornošću na gljivične bolesti već su duže godina poznate javnosti, zastupljene su u proizvodnji i dio su oplemenjivačkih programa drugih zemalja, a većina ranije navedenih nastala je prije otprilike 40 godina. Prema Eibach and Töpher (2003.), Regent je nastao križanjem sorata Diana i Chambourcin 1967. godine, selekcioniran je iz populacije 1972., a u periodu od 1985. do 1996. postavljeno je više od 200 pokusnih nasada diljem njemačkih vinorodnih regija, kada je započet proces klasifikacije pri Europskoj Zajednici nakon čega je i službeno uvršten u popis sorata za proizvodnju kvalitetnih vina. Otada se provode brojna ocjenjivanja vina od ove i ostalih otpornih sorata, koje redovito postižu „,velika zlata“ odnosno 
više od 95 bodova (https://piwi-international.de/en/piwi-wine-award/piwi-wine-award-2019/ results-2019/).

\section{Italija}

Počeci oplemenjivačkih programa u Italiji datiraju od 19. stoljeća, a obuhvaćali su hibridizaciju stolnih sorata i podloga kao i u drugim Europskim zemljama nakon pojave filoksere (Bavaresco i sur., 2015.). Aktualni oplemenjivački programi obuhvaćaju: oplemenjivanje loznih podloga na tolerantnost na sušu i fiziološki aktivno vapno i kreiranje novih vinskih sorata $s$ otpornošću prema pepelnici i plamenjači uz poboljšanje svojstava kvalitete intraspecifičnim križanjemautohtonih iinternacionalnih sorata.

Oplemenjivački program za otpornost na najvažnije bolesti pokrenut 1998. godine na Sveučilištu u Udinama za cilj ima introdukciju otpornosti na bolesti iz europskih naprednih uzgojnih linija i divljih vrsta u internacionalne i autohtone sorte vinove loze (Bavaresco i sur., 2015.). Teissedre, (2018.) navodi kako je selekcija u ovom programu primarno bazirana na križanjima sorata poput Tocai, Sauvignon bijeli, Merlot i Cabernet Sauvignon sa njemačkim ili mađarskim sortama poznatim po svojoj otpornosti poput Biance, Regenta ili Kozme 20-3. Foria i sur., (2019.) navode kako su za roditeljske parove, uz navedene sorte korištene i sorte Chardonnay, Grenache, Aglianico, Pinot crni, Malvasia di Candia aromatica, Cabernet Sauvignon, Soreli, Traminac, Muškat bijeli, Rajnski rizling, Sangiovese, Barbera, Regina, Vittoria, Italia, Matilda i Lasta, a u periodu od 2010. do 2013. dobiveno je ukupno 6000 sjemenjaka iz 71 križanja, a s obzirom da su koristili strategiju piramidiziranja, činjenica da je 70 \% križanaca sadržavalo 2 ili 3 gena za otpornost, pokazala je uspjeh. Teissedre, (2018) navodi kako je rezultat programa Sveučilišta Udine rezultirao sa deset sorata predloženih za registraciju u talijanskom katalogu sorata: Fleurtai, Soreli, Early Sauvignon, Petit Sauvignon, Sauvignon Doré, Petit Merlot, Royal Merlot, Petit Cabernet, Royal Cabernet i Julius.

Vezzulli i sur., (2019.) navodi kako program genetskog poboljšanja otpornosti na biotičke stresore, započet u Fondazione Edmund Mach (FEM) 2010. godine, ima dva cilja: prvi je razviti nove sorte otporne na patogene, s visokom razinom kvalitete, koje su spremne biti plasirane na tržište, dok je drugi razviti superdonore otpornosti koji će djelovati kao učinkovitiji roditelji za buduće uzgojne programe, prenoseći osobine otpornosti svim potomcima. Također spominje mogućnost puštanja u promet osam novih sorata sa jednim do tri lokusa za otpornost $u$ narednih deset godina.

Važno je napomenuti kako je navedeni program (FEM) rezultirao otkrićem markera povezanih s veličinom bobica, besjemenosti, količinom monoterpena, muškatnim aromama, varijacijama koncentracije antocijana i spolom cvjetova.

\section{Zaključak}

Ovim je radom dan je pregled najčešće korištenih tehnika i metoda za oplemenjivanje najvažnije voćne vrste na svijetu. Usprkos višestoljetnim naporima i dobivenim značajnim rezultatima klasičnih oplemenjivačkih metoda, pogotovo u pogledu otpornosti na biotičke stresore, kao i abiotičke, poput suše ili mraza, daljnja primjena molekularnog oplemenjivanja bit će moguća samo ako se istraži sva dostupna germplazma vinove loze i njezinih divljih rođaka na svijetu jer je konstantnim križanjima nove generacije hibrida, nemoguće u genom vinove loze unijeti novu genetsku varijabilnost. Javnost, posebice u zemljama starog svijeta nije sklona prihvaćanju novih, hibridizacijom dobivenih sorata u proizvodnji vina, tako da se iako dostupni, otporne sorte i dalje najviše sade vrlo ograničeno.

S obzirom na sve izraženije globalne klimatske promjene i pomicanje uzgojnog areala vinove loze, mnoge su države poput Kanade, Brazila, USA, Kine, Rusije i Mađarske, a i Norveške 
i Ujedinjenog Kraljevstva, gdje donedavno nije bilo moguće uzgajati plemenitu vinovu lozu, objeručke prihvatile nove otporne sorte i omogućile razvoj vinogradarske proizvodnje.

Uvođenjem otpornih sorata u proizvodnju, smanjit će se negativan ekološki utjecaj u pogledu prekomjerne uporabe sredstava za zaštitu bilja, barem vezanih uz pepelnicu i plamenjaču, no ne i potpuno ukidanjem svih zaštitnih mjera zbog drugih bolesti koje su dosad smatrane „sekundarnim“. Unos poželjnih gena otpornosti konvencionalnim oplemenjivanjem je veoma skup i dugotrajan proces, a posljednjih godina je već uočen slom rezistencije pojedinih gen lokusa za otpornost. Danas se sve više diskutira o mogućnosti prihvaćanja genetski uređenih biljaka posebno korištenjem gena otpornosti koji su prisutni u drugim vrstama loza.

Unatoč neizmjernom potencijalu novih kombinacija gena prijeko je potreban razvoj adekvatnih tehnika i dugogodišnjih ispitivanja stabilnosti njihove ekspresije. Potencijalno nepoznati učinci uzrok su velikog otpora i zabrinutosti zakonodavaca i potrošača. Izazovi oplemenjivanja vinove loze u budućnosti uvelike će se oslanjati na uvođenje novih metoda s ciljem suočavanja s abiotskim i biotskim čimbenicima stresa, stvaranja superdonora, ali i edukacije i šire javnosti.

Obzirom na sve izraženije globalne klimatske promjene i pomicanje uzgojnog areala vinove loze, države poput Kanade, Brazila, SAD, Kine, Rusije i Mađarske, a i Norveške i Ujedinjenog Kraljevstva, gdje donedavno nije bilo moguće uzgajati plemenitu vinovu lozu, danas su primjeri dobre prakse kao pioniri uzgoja novih otpornih sorti.

\section{Literatura}

Anderson, K., Aryal, N. R. (2020) Which Winegrape Varieties are Grown Where?: A Global Empirical Picture. (ažurirano izdanje) Adelaide: The University of Adelaide Press. 978-1-925261-86-8 www.adelaide.edu.au/press/titles/winegrapes

Bavaresco, L., Gardiman, M., Brancadoro, L., Espen, L., Failla, O., Scienza, A., Vezzulli, S., Zulini, L., Velasco, R., Stefanini, M., Di Gaspero, G., Testolin, R. (2015) Grapevine breeding programs in Italy, U Reynolds, A.: Grapevine Breeding Programs for the Wine Industry. Cambridge: Elsevier, https://doi.org/10.1016/B978-1-78242-075-0.00007-7

Buonassisi, D., Colombo, M., Migliaro, D., Dolzani, C., Peressotti, E., Mizzotti, C., Velasco, R., Masiero, S., Perazzolli, M., Vezzulli, S. (2017) Breeding for grapevine downy mildew resistance: a review of “omics” approaches. Euphytica $213,103$. https://doi.org/10.1007/s10681-017-1882-8

Dalla Costa, L., Malnoy, M., Gribaudo, I. (2017) Breeding next generation tree fruits: technical and legal challenges. Hortic. Res. 4, 17067. https://doi.org/10.1038/hortres.2017.67

Dalla Costa, L., Malnoy, M., Lecourieux, D., Deluc, L. Ouaked- Lecourieux, F., Thomas, M.R., Torregrosa, L.J.-M. (2019) The state-of-the-art of grapevine biotechnology and new breeding technologies (NBTS). OENO One 53, $189-212$. https://doi.org/10.20870/oeno-one.2019.53.2.2405

Daniela, P., Federica, G., Mirella, G., Diego, T. (2013) Performance of interspecifi grapevine varieties in north-east Italy. Agric. Sci. 04, 91-101. https://doi.org/10.4236/as.2013.42015

Dalbo, M.A. (1998) Genetic mapping, QTL analysis and marker-assisted selection for disease resistance loci in grapes. Ph.D. Thesis, Cornell Univ., Ithaca, NY.

Di Gaspero, G., Cattonaro, F. (2010) Application of genomics to grapevine improvement. Aust. J. Grape Wine Res. 16, 122-130. https://doi.org/10.1111/j.1755-0238.2009.00072.x

Dong, Q.-H., Cao, X., Yang, G., Yu, H.-P., Nicholas, K.K., Wang, C., Fang, J.-G. (2010) Discovery and characterization of SNPs in Vitis vinifera and genetic assessment of some grapevine cultivars. Sci. Hortic. 125, 233-238. https://doi. org/10.1016/j.scienta.2010.03.023

Eibach, R., Töpher, R. (2003) SUCCESS IN RESISTANCE BREEDING: “REGENT” AND ITS STEPS INTO THE MARKET. Acta Hortic. 687-691 https://doi.org/10.17660/ActaHortic.2003.603.95

Eibach, R., Zyprian, E., Welter, L., Töpfer, R. (2007) The use of molecular markers for pyramiding resistance genes. Vitis 46 (2), 120-124. https://doi.org/10.5073/vitis.2007.46.120-124

Fischer, B.M., Salakhutdinov, I., Akkurt, M., Eibach, R., Edwards, K.J., Töpfer, R., Zyprian, E.M. (2004) Quantitative trait locus analysis of fungal disease resistance factors on a molecular map of grapevine. Theor. Appl. Genet. 108, 501-515. https://doi.org/10.1007/s00122-003-1445-3

Foria, S., Monte, C., Testolin, R., Di Gaspero, G., Cipriani, G. (2019) Pyramidizing resistance genes in grape: a breeding program for the selection of elite cultivars. Acta Hortic. 549-554. https://doi.org/10.17660/ActaHortic.2019.1248.73

Frank, M. H., Chitwood, D. H. (2016) Plant chimeras: The good, the bad, and the "Bizzaria." Developmental Biology, 419(1), 41-53. doi:10.1016/j.ydbio.2016.07.003

Franks, T., Botta, R., Thomas, M.R., Franks, J., (2002) Chimerism in grapevines: implications for cultivar identity, ancestry and genetic improvement. Theor. Appl. Genet. 104, 192-199. https://doi.org/10.1007/s001220100683

Gray, D.J., Li, Z.T., Dhekney, S.A. (2014) Precision breeding of grapevine (Vitis vinifera L.) for improved traits. Plant Sci. 228, 3-10. https://doi.org/10.1016/j.plantsci.2014.03.023

Guimier, S., Delmotte, F., Miclot, A.S., Fabre, F., Mazet, I., Couture, C., Schneider, C., Delière, L. (2019) OSCAR, a national observatory to support the durable deployment of disease-resistant grapevine cultivars. Acta Hortic. 21-34. https://doi. org/10.17660/ActaHortic.2019.1248.4

Kikkert, J.R., Thomas, M.R., Reisch, B.I. (2001) Grapevine Genetic Engineering, U: Roubelakis-Angelakis, K.A. (Ed.), 
Molecular Biology \& Biotechnology of the Grapevine. Dordrecht: Springer 393-410. https://doi.org/10.1007/978-94-0172308-4 15

Māletić, E., Karoglan Kontić, J. i Pejić, I. (2008) Vinova loza : ampelografi ekologija, oplemenjivanje. Zagreb: Školska knjiga. ISBN 978-953-0-31148-0

Malnoy, M., Viola, R., Jung, M.-H., Koo, O., Kim, S., Kim, J.-S. (2016) DNA-free genetically edited grapevine and apple protoplast using CRISPR/Cas9 ribonucleoproteins. Front. Plant Sci. 7:1904. doi: 10.3389/fpls.2016.01904

Meredith, C. P. (2001) Grapevine Genetics: Probing the Past and Facing the Future, Agriculturae Conspectus

Scientifi , Vol. 66, No. 1, 2001 21-25.

Merdinoglu, D., Schneider, C., Prado, E., Wiedemann-Merdinoglu, S., Mestre, P. (2018) Breeding for durable resistance to downy and powdery mildew in grapevine. OENO One 52, 203-209. https://doi.org/10.20870/oenoone.2018.52.3.2116

Metje-Sprink, J., Menz, J., Modrzejewski, D., Sprink, T. (2019) DNA-Free Genome Editing: Past, Present and Future.

Front. Plant Sci. 9, 1957. https://doi.org/10.3389/fpls.2018.01957

Pedneault, K., Provost, C. (2016) Fungus resistant grape varieties as a suitable alternative for organic wine

production: Benefi , limits, and challenges. Sci. Hortic. 208, 57-77. https://doi.org/10.1016/j.scienta.2016.03.016

Perl, A., Eshdat, Y. (1998) DNA Transfer and Gene Expression in Transgenic Grapes. Biotechnol. Genet. Eng. Rev. 15,

365-386. https://doi.org/10.1080/02648725.1998.10647962

Peterlunger, E., Di Gaspero, G., Cipriani, G., Sivilotti, P., Zulini, L., Marrazzo, M.T., Andreetta, D., Testolin, R. (2003)

BREEDING STRATEGY FOR THE INTROGRESSION OF DISEASE RESISTANCE GENES INTO EUROPEAN GRAPEVINE. ACTa Hortic. 665-670. https://doi.org/10.17660/ActaHortic.2003.603.91

Preiner, D., Marković, Z., Šikuten, I., Maletić, E., Karoglan Kontić, J., Mihovilović, A.B., Žulj Mihaljević, M. (2019) In vitro

synthesis of grapevine (Vitis vinifera L.) intraspecifi chimeras using meristematic bulk tissue grafting. Sci. Hortic. 246,

965-970.https://doi.org/10.1016/j.scienta.2018.11.085

Reynolds, A. (2015) Grapevine breeding programs in Italy, in: Grapevine Breeding Programs for the Wine Industry.

Cambridge: Elsevier, pp. https://doi.org/10.1016/B978-1-78242-075-0.00007-7

Riaz, S., Tenscher, A., Pap, D., Romero, N., Walker, M.A. (2019) Durable powdery mildew resistance in grapevines:

myth or reality. Acta Hortic. 595-600. Proc. XII International Conference on Grapevine Breeding and Genetics https://doi. org/10.17660/ActaHortic.2019.1248.80

Ruehl, E., Schmid, J., Eibach, R., Töpfer, R. (2015) Grapevine breeding programmes in Germany. U: Reynolds, A:

Grapevine Breeding Programs for the Wine Industry. Cambridge: Elsevier, https://doi.org/10.1016/B978-1-78242-075-

0.00007-7

Sabbadini, S., Capriotti, L., Limera, C., Navacchi, O., Tempesta, G., Mezzetti, B. (2019) A plant regeneration platform to apply new breeding techniques for improving disease resistance in grapevine rootstocks and cultivars. BIO Web Conf. 12, 01019. https://doi.org/10.1051/bioconf/20191201019

Salmon, J.-M., Ojeda, H., Escudier, J.-L. (2018) Disease resistant grapevine varieties and quality: the case of Bouquet varieties. OENO One 52, 225-230. https://doi.org/10.20870/oeno-one.2018.52.3.2139

Saporta, R., San Pedro, T., Gisbert, C. (2017) Attempts at grapevine (Vitis vinifera L.) breeding through genetic tran-

sformation: The main limiting factors. VITIS - J.Grapevine Res. 55, 173-186. https://doi.org/10.5073/VITIS.2016.55.173-186 Scheben, A., Edwards, D (2017) Genome editors take on crops. Science 355, 1122-1123. https://doi.org/10.1126/science.aal4680

Schneider, C., Onimus, C., Prado, E., Dumas, V., Wiedemann-Merdinoglu, S., Dorne, M.A., Lacombe, M.C., Piron, M.C., Umar-Faruk, A., Duchêne, E., Mestre, P., Merdinoglu, D. (2019) INRA-ResDur: the French grapevine breeding programme for durable resistance to downy and powdery mildew. Acta Hortic. 207-214. https://doi.org/10.17660/ActaHortic.2019.1248.30

Shidfar, M., Akkurt, M., Atak, A., Ergül, A., Söylemezoğlu, G. (2019) EVALUATION OF GRAPEVINE RESISTANCE TO DOWNY AND POWDERY MILDEW IN 'REGENT'× 'BOĞAZKERE' HYBRID POPULATION SEGREGATING FOR RESISTANCE GENES. Acta Sci. Pol. Hortorum Cultus 18, 181-188. https://doi.org/10.24326/asphc.2019.1.18

Sivcev, B., Sivcev, I., Rankovic-Vasic, Z. (2010) Natural process and use of natural matters in organic viticulture. J. Agric. Sci. Belgrade 55, 195-215. https://doi.org/10.2298/JAS1002195S

Teissedre, P.-L. (2018) Composition of grape and wine from resistant vines varieties. OENO One 52, 211-217. https:// doi.org/10.20870/oeno-one.2018.52.3.2223

Tomic, L., Stajner, N., Javornik, B. (2013) Characterization of Grapevines by the Use of Genetic Markers, in: Sladonja, B.

(Ed.), The Mediterranean Genetic Code - Grapevine and Olive. InTech. https://doi.org/10.5772/52833

Töpfer, R., Hausmann, L., Harst, M., Maul, E., Zyprian, E., Eibach, R. (2011) New Horizons for Grapevine Breeding, Fruit, Veget and Cereal Sci and Biotech 5 (Special Issue 1), 79-100.

Veillet, F., Durand, M., Kroj, T., Cesari, S., Gallois, J.-L. (2020) Precision Breeding Made Real with CRISPR: Illustration through Genetic Resistance to Pathogens. Plant Commun. 100102. https://doi.org/10.1016/j.xplc.2020.100102

Vezzulli, S., Dolzani, C., Migliaro, D., Banchi, E., Stedile, T., Zatelli, A., Dallaserra, M., Clementi, S., Dorigatti, C., Velasco, R., Zulini, L., Peressotti, E., Stefanini, M. (2019) The Fondazione Edmund Mach grapevine breeding program for downy and powdery mildew resistances: toward a green viticulture. Acta Hortic. 109-114. https://doi.org/10.17660/ActaHortic.2019.1248.16

Weising, K. (2005) DNA fi printing in plants: principles, methods, and applications, 2nd ed. Boca Raton: Taylor \& Francis Group

Yobrégat, O. (2018) Introduction to resistant vine types : a brief history and overview of the situation. OENO One 52,

241-246. https://doi.org/10.20870/oeno-one.2018.52.3.2220

Zini, E., Raffeiner, M., Di Gaspero, G., Eibach, R., Grando, M.S., Letschka, T. (2015) Applying a defi set of molecular markers to improve selection of resistant grapevine accessions. Acta Hortic. 73-78. https://doi.org/10.17660/ActaHortic.2015.1082.9

Pravilnik o Nacionalnoj listi priznatih kultivara vinove loze NN 53/2014. https://narodne-novine.nn.hr/clanci/sluzbeni/2014_04_53_1007.html(14.09.2020.)

Pravilnik o Nacionalnoj listi priznatih kultivara vinove loze NN 25/2020 https://narodne-novine.nn.hr/clanci/sluzbeni/2020_03_25_616.html (15.09.2020.)

Endure diversifying crop protection http://www.endure-network.eu/content/download/5586/43605/fi apevi- 
ne\%20Case\%20Study\%20Guide\%20Number\%205.pdf (1.09.2020.)

CuriaEuropa http://curia.europa.eu/juris/documents.jsf?language=EN\&critereEcli=ECLI:EU:C:2018:583 (12.09.2020.)

The World of Organic Agriculture 2020 https://www.organic-world.net/yearbook/yearbook-2020/pdf.html ; (u tekstu kao FIBL i IFOAM, 2020.) (11.09.2020.)

Prispjelo/Received: 29.10.2020.

Prihvaćeno/Accepted: 30.11.2020.

Review paper

\title{
A review of grapevine (Vitis vinifera L.) \\ breeding programs in Europe
}

\begin{abstract}
Modern viticulture and winemaking are based on the dominant use of a small number of well-known grape varieties of common grapevine (Vitis vinifera L.) species, which are highly susceptible to major viticultural diseases such as downy (Plasmopara viticola Berk \& Curt.) and powdery mildew (Erysiphe necator Schwein.). Changes of assortment in cultivation are quite slow due to the conservative and traditional approach of both producers and consumers of grapes and wine. Viticultural production is one of the largest consumers of pesticides, especially fungicides and insecticides compared to all other types of agricultural production systems and as such has a significantly negative impact on the environment and the health of people working in the wine sector. Today, numerous breeding programs have been launched in the world to create new varieties resistant to diseases that will be comparable in quality and other characteristics to traditional varieties of certain areas. This paper presents the most important breeding methods and programs that are currently carried out on grapevines in Europe.
\end{abstract}

Keywords: Vitis vinifera, resistant varieties, hybrids, breeding

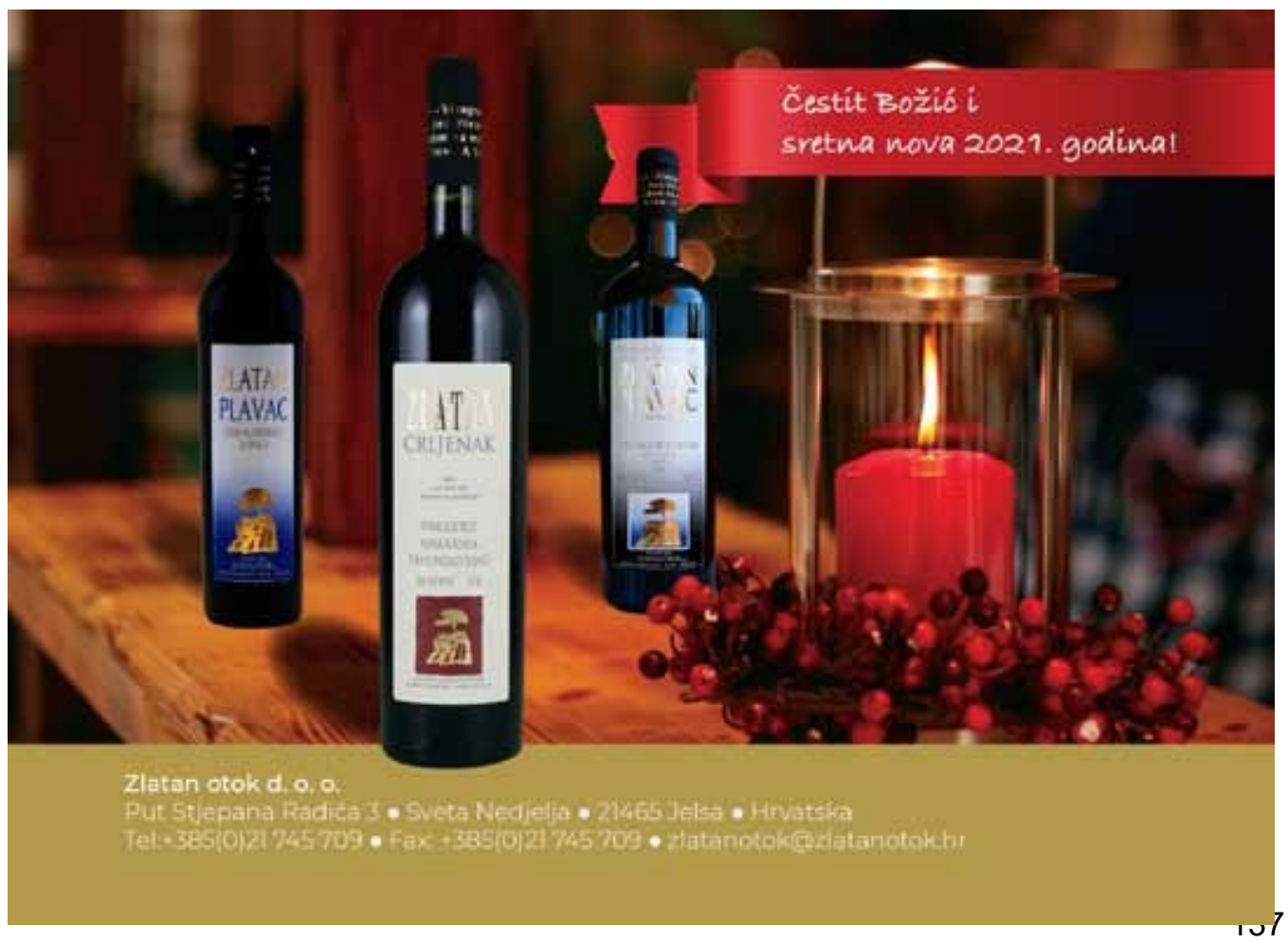

